\title{
Android Model-Based T-Mobile Learning to Improve Students' Listening Capability
}

\author{
W.H. Setyawan, Rusijono \& M. Jannah \\ Universitas Negeri Surabaya, Surabaya
}

\begin{abstract}
The study was conducted to develop the students' listening capability by using t-mobile learning android modelbased. It provides suggestions about how to perform an appropriate model based on android application. The subjects were 60 students who have undertaken the listening program in 2016 until 2017. There were only two variables studied, including the T-mobile learning model, and the students' listening capability. The study used a quantitative method. The findings of this research showed that the feasibility of t-mobile learning and the students` listening capability were sufficient and appropriate.
\end{abstract}

Keywords: T-mobile learning, Listening capability

\section{INTRODUCTION}

Students who learn English encounter some difficulties in learning listening comprehension, so they need training with a good technique. They are not only the exercises and techniques that can support the learning process but also the learning design as well as the facilities. The basis of student's problems is the weak vocabulary mastery and the students' ability to understand and analyze the message delivered by the speaker (native speaker) with rapid listening speed. Therefore, it makes them feel difficult to catch the message in the conversation. The obtained data in the preliminary study shows that the vocabulary mastery and listening speed of students still below the standard minimum mark. So, they need a special treatment to improve the ability.

T-mobile learning is a pattern of learning designed to improve students' listening skills. It develops Android applications on mobile learning or smartphone as a listening media. The results of the study Nicholas \& Ng, (2012) stated that a mobile learning could be used in the learning process. The character of mobile learning that can be developed is based on Android on smartphones, tablets, double tabs and swipe. That way the design must use the server and host to control learning and easier in updating the contents of the material provided to students to be able to work more leverage. As well as various other problems on mobile learning devices that are more specific. Mobile technology has the power to promote and encourage the fundamental social interactions to learn and connect with others (Ching et al., 2009). To get the maximum results of mobile learning program implementation is by providing a learning experience in social and informatics environments as well as to support unique interactions that are useful for the learning process (Ting, 2011). Mobile technology allows the students to be able to move simultaneously both physically, digitally and communicatively. This mobility can be achieved individually, paired with small groups or entire classes with learners, mentors, experts, professionals, and others (Chen et al., 2011). The existence of a mobile learning has some purposes, namely to provide information to individuals about the practice of the specific theme, to prepare the individuals regarding to the development of capabilities and training in the field of the selected job, to develop the individuals' knowledge as a requirement for performing continuously changing work and to give experience to individuals if later there is a transition of work in the workplace, either by his own choice or requested by the company/ workplace (Billett, 2011).

Based on the objectives of t-mobile learning above, it is undeniable that the model must be applied to the listening students. The students' real experience in the field of the workplace will be invaluable for the students' capability.

However, the proportion of students and lecturers is imbalanced. The lecturers who guide and evaluate the students are limited, and this results in the poor monitoring process of the students by the lecturer (Koc et al., 2014). During the tmobile learning program (1-3 months), the lecturer monitors the minimum of three times to discover the progress of the students. However, if the distance from the campus to the student living is too far, there will be another problem. To solve these problems, the use of an 'Online Diary' is required for students. The students must fill out the diary once a week to share what they learn during the internship program. This would help the assessment process to be more effective (Koc et al., 2014). The results of the study from 40 students who have already implemented the "Online Internship Journal System" indicate that most interns react positively to the learning and the reflective processes embedded in journal writing (Chanlin \& Hung, 2015).

According to Anderson \& Lynch in 1988, all basic listening mastery must be rehearsed repeatedly and continually in a gradual manner. It cannot be done only at face-to-face learning in a classroom that is only 2 credits. Therefore, students need media technology development that they can use to practice their listening skills to keep increasing. 
According to some references, good practice for listening is characterized by certain aspects. In the aspect of working practice, the students are facilitated to work in groups so that the weakest students will have increased competency (Binder et al., 2015). In addition, students complete a routine journal that can provide guidance to students in achieving the goals of it (Gaba et al., 2015).

The development of mobile learning has been predicted that in the future will be the lifestyle of every person with easy to access information, run the application, and can to improve one's self-ability in listening mastery to make the source of learning AECT (2008). The large and the number of users of car devices among students make it a challenge as well as the challenges of learning-based mobile learning designers. Opportunities that can be created is how learning that can improve vocabulary mastery, control listening speed repeatedly through mobile learning applications in the control via host and server to store data by admin. Now students can learn anytime and anywhere either through off-line or online to download the learning material. The app can be run either at home, in a vehicle or in a public place whenever an access it.

As a learning designer based on mobile learning applications, it will focus on the content of materials, strategy design, learning model but for technical matters, it can collaborate with application programmer's Android-based mobile learning that is more expert and experienced in the field. Therefore, in the need of a learning model that acts as a framework in the development of mobile learning-based learning model is to create Android-based applications that mixed with the content of the material according to what the students need with the thematic approach is expected to improve the students' listening skills. So that the researchers interested in developing a model of learning that needs to get testing by model experts who are expected to improve listening skills of students are to test the feasibility of t-mobile learning model based on Android to improve student listening skills.

\section{METHOD}

This study uses quantitative and qualitative research with research and development (R\&D) approach. The research development or Research and Development (R\&D) produces mobile learning application development model which is expected to improve students' listening ability. The research design used Dick and Carey as the model development stage. This research was conducted at Universitas Islam Kadiri, Kediri located at J1. Sersan Suharmaji 38 Kediri, District: Manisrenggo, Kediri. The data were collected through questionnaires, literature reviews and interviews.
The procedure in this research is shown in Figure 1:

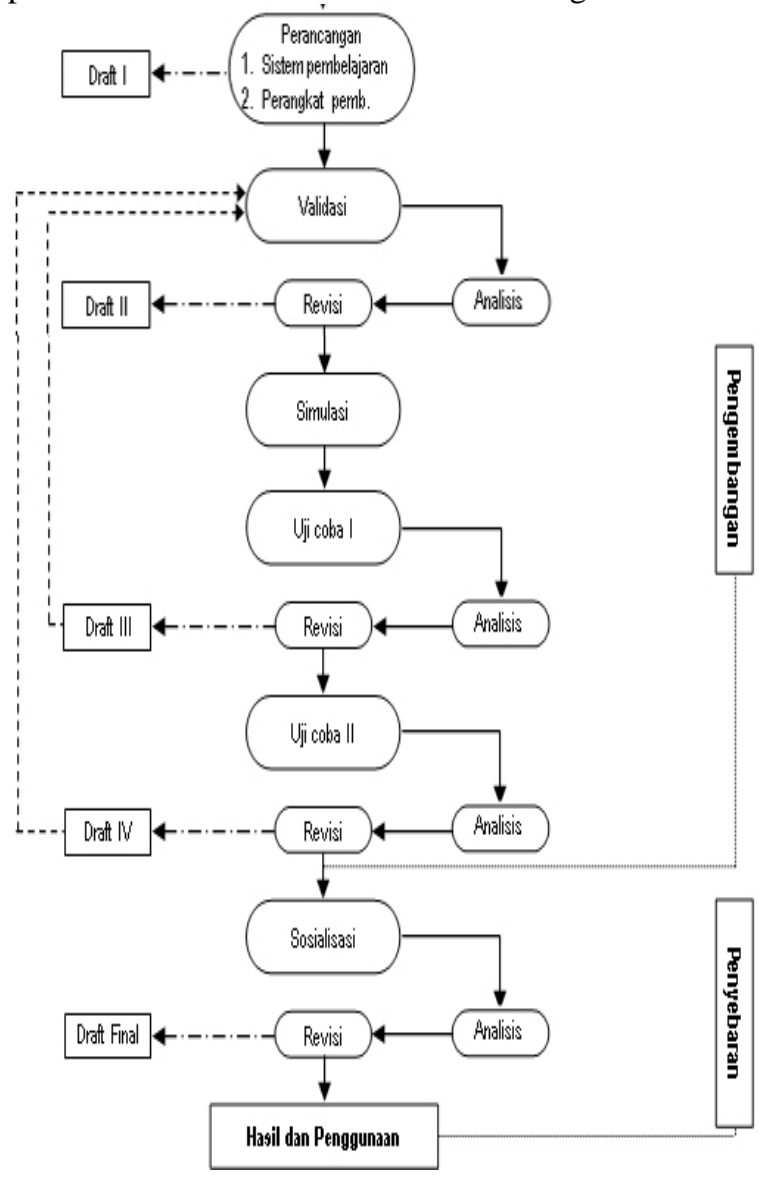

Fig. 1. Research procedure.

The questionnaire has been compiled and shown to the supervisor for revision. Furthermore, to test the validity, the questionnaire was tested by distributing questionnaires to the expert of the learning model. The questions that pass the validity test are compiled into the questionnaire used in the study, which was then distributed to the expert of the model, language material and application. The data collected from the questionnaire were processed, presented and analyzed. The results of the analysis are used to provide conclusions and recommendations.

A field study was conducted by interviewing a few students who had already applied the listening subject, regarding the implementation of the application in terms of service satisfaction aspects, process guidance with the supervisor, guidance process with the supervisor from industry and the final evaluation. The interview results can be included in the questionnaire and formulation of the problem.

\section{RESUlt AND DisCUSSION}

The data collection technique is conducted by using the System Approach, the Dick and Carey Model is as follows: 1 . Identifying Learning Objectives; 2. Conducting Learning 
Analysis; 3. Analyzing Learners and Contexts; 4. Formulating Special Purpose of Learning or Indicator; 5. Developing Assessment Instruments; 6. Developing Learning Strategies; 7. Develop and select learning materials; 8. Designing and conducting Formative Evaluation Instructions; 9. Revise the Learning Program; 10.Summative Eva, with the number of validation expert as shown in Table 1:

Table 1 Number of respondents from the expert.

\begin{tabular}{|c|c|c|c|}
\hline No & Class & Indicator & Score $(\%)$ \\
\hline 1 & Valid & $\begin{array}{l}\text { Valid Already got } \\
\text { expert validation/ } \\
\text { model expert }\end{array}$ & 4 \\
\hline \multirow[t]{3}{*}{2} & Practical & *Can theoretically & 4 \\
\hline & & $\begin{array}{l}\text { be carried out in } \\
\text { learning }\end{array}$ & 4 \\
\hline & & $\begin{array}{l}\text { *In principle can be } \\
\text { applied in the } \\
\text { classroom }\end{array}$ & \\
\hline \multirow[t]{2}{*}{3} & Effective & $\begin{array}{l}* \text { States that the } \\
\text { model is effective }\end{array}$ & 4 \\
\hline & & $\begin{array}{l}\text { *In the } \\
\text { implementation of } \\
\text { the model gives } \\
\text { results as expected }\end{array}$ & 3 \\
\hline \multirow[t]{2}{*}{4} & Objectives & $\begin{array}{l}\text { *Learning models } \\
\text { are designed to } \\
\text { achieve specific }\end{array}$ & 4 \\
\hline & & $\begin{array}{l}\text { learning goals. } \\
* \text { The purpose of } \\
\text { learning has a } \\
\text { strong foundation } \\
\text { of thought }\end{array}$ & 4 \\
\hline \multirow[t]{3}{*}{5} & Syntax & $\begin{array}{l}* \text { The designed } \\
\text { learning model has } \\
\text { a clear syntax }\end{array}$ & 4 \\
\hline & & $\begin{array}{l}\text { * Each of the } \\
\text { designed syntax } \\
\text { items has a strong }\end{array}$ & 4 \\
\hline & & $\begin{array}{l}\text { theoretical } \\
\text { foundation } \\
\text { * The order of } \\
\text { syntax is logically } \\
\text { arranged }\end{array}$ & 4 \\
\hline 6 & $\begin{array}{l}\text { Supporting } \\
\text { Systems }\end{array}$ & $\begin{array}{l}* \text { The learning } \\
\text { model has a } \\
\text { supporting system }\end{array}$ & 4 \\
\hline & & $\begin{array}{l}\text { component } \\
\text { * Supported systems } \\
\text { are structured to } \\
\text { have a strong } \\
\text { theoretical basis. }\end{array}$ & 4 \\
\hline 7 & $\begin{array}{l}\text { Social } \\
\text { systems }\end{array}$ & $\begin{array}{l}* \text { The learning } \\
\text { model is designed } \\
\text { to have a social } \\
\text { system component. }\end{array}$ & 4 \\
\hline
\end{tabular}

* Components of the social system that are structured clearly illustrate the role of teachers and students.

* The components of the social system are arranged to illustrate the pattern of relationship or communication between teachers and students

* Components of the social system that are prepared to describe the expected target

\section{Reaction}

* The learning principles model is designed to have a reaction principle component.

* The reaction principle composite component illustrates how teachers should see and treat students, both individually and in groups, as well as in their entirety. Result: 67

Total 75

In Table 1, it can be seen that the validation model shows the acquisition of $75 \%$. It shows valid criteria. Model experts also provide suggestions and suggestions that can be described on a suggestion sheet. Suggestions for the model are: 1) to create and develop the model before the spider application is made, and 2) there is a sentence that is too long, the assessment instrument to assess the liveliness.

Tables 2 to 5 show the results of the respondents' data processing from the material of the expert:

Table 2. Result of the data processing for the variable: the expert material.

\begin{tabular}{lll}
\hline No & \multicolumn{1}{c}{ Indicator } & $\begin{array}{l}\text { Score } \\
(\%)\end{array}$ \\
\hline 1 & $\begin{array}{l}\text { The integration of selected instructional } \\
\text { content }\end{array}$ & 3 \\
2 & $\begin{array}{l}\text { Ideal material/ theme breadth, not too narrow } \\
\text { and not too broad }\end{array}$ & 3 \\
& 3
\end{tabular}


3 The learning ability to accommodate the diversity of individuals 4

4 Suitability of learning with the level of student development

5 Accommodation on a wide range of intelligence

6 Emergence of teacher-student interaction, students-students

7 The material presented includes all the materials listed in the core competencies and basic competencies

8 The material in accordance with basic material 3 needs that support the achievement of core competence (KI) and basic competence (KD) 4

9 The material presented accurately to avoid misconceptions by students

10 Facts and data presented in accordance with the reality and efficiency to improve students' understanding

11 The example presented in the material is an accurate example

12 Clarity of examples given to each learning 4 activity

13 The clarity of the indicators illustrates the 3 achievement of measurable learning outcomes

14 Problems presented in accordance with the material

15 Clarity of introductory description to encourage student improvement to learn more

16 The images are presented in accordance with reality and efficiency to improve students' understanding.

17 The material presented actual that is in accordance with the development of scholarship and characteristics of students

18 The actual image is given

19 Examples and cases are presented in accordance with the situation and conditions around

20 Compatibility between the questions on learning activities with the indicators of learning outcomes

21 The key answers are in accordance with the question and are easy to use to carry out independent activities

22 References easy to use as a source of support that can be used as a reference to find sources of reading that are relevant to the material

23 The use of real situations, the authenticity of the learning experience

24 Availability of learning resources in the immediate environment of students

25 The significance of the learning experience.

26 Giving responsibility to students either individually or in groups Jumlah
Table 3. Result of the data processing for the variable: feasibility of application

No

Questions

Score
1 The sentence represents the contents of the message or information to be conveyed with still following the appropriate sentence.

2 Sentences are simple and direct to the target

3 Messages presented with interesting, clear, right on target, does not give rise to double

$4 \quad$ meaning

The language used evokes pleasure when students read it

5 Ability to motivate students with the level of student development

$6 \quad$ Submission between adjacent paragraphs and sentences in paragraphs reflects a logical relationship

Consistent use of symbols or icons in the application

Consistent use of symbols or icons in the application

Total 28

Percentage $87,50 \%$

Based on the data in Table 2, the procedures for implementing the t-mobile learning in the Education Department still need some improvement. Also, there is a cooperation between the department, designer and programmer regarding the t-mobile learning. Based on the data in Table 3, the feasibility of application is good.

\section{CONCLUSION}

Based on the respondent data and internship evaluation standards, the procedures for feasibility of t-mobile learning model in the FKIP Education Department still need some improvements because of the lack of socialization to the students and have no cooperation between the English department and company regarding that model. The results of the respondent data, the validation of the model is good; 2) to produce the feasibility of product model of t-mobile learning by designing learning; 3) to create an Android-based mobile learning application that can be accessed easily and can be used in the learning process to improve student listening ability effectively. 


\section{REFERENCES}

Binder, J. F. et al. (2015). The academic value of internships : Benefits across disciplines and student backgrounds. Contemporary Educational Psychology,41, 73-82.

Chaplin, J. (2005). KamusLengkapPsikologi.Jakarta: Rajawali Press.

Chen, M.-C., Jiann-Liang, C., \&Teng-Wen, C. (2011).Android/OSGi-Based Vehicular network management system.Computer Communications, 34, 169183.

Ching, D. C., Lewis, A., \& Michael, H. L. (2009). Harnessing the Potential of Mobile Technologies for Children and Learning.Mobile Technology for Children Desaining for interaction and learning.

Comer, L. B., \&Drollinger, T. (1999).Active empathetic Listening and Selling Success: A Conceptual framework.Journal of Personal Selling and Sales Management, , 15-29.

Dick , W., Carey, L., \& Carey, J. (2015). The Systematic Design of Instruction. Florida: Pearson.

Dick, W., Carey, L., \& Carey, J. O. (2009).The System Design of Instruction. New Jersey: Pearson.

Ele. (2000). Ananalisis and Evaluation of Structural Change. melbourne, Australia: Monash University.

Gaba, A., Rd, E. \& Cde, C.D.N. (2015). Development and evaluation of an e-portfolio for use in a dietetic internship program. Procedia - Social and Behavioral Sciences, 174, 1151-1157.
Koc, E. et al. (2014). Leisure, sport \& tourism education Are internship programs encouraging or discouraging? - A viewpoint of tourism and hospitality students in Turkey. Journal of Hospitality, Leisure, Sport \& Tourism Education, 15, 135-142.

Nah, K., White , P., \& Sussex , R. (2008). The potential of using a mobile phone to access the Internet for learning EFL listening skills within a Korean context.ReCALL, 20(3).doi: https://doi.org/10.1017/S0958344008000633

Nikerson, R. S., \&Zodhiates, P. P. (1991).Technology in education: Looking toword 2020.Education technology research and development., 39.

Nicholas, L. B., \&Ng.Weaver, B. E. (2005).Enhancing Learning with Laptops in the Classroom the Directions for Teaching and Learning. San Franscisco: Jossey Bass.

Ozdemir, S. (2010). Colloquium: Supporting printed books with multimedia: A new way to use mobile technology for learning. British journal of Educational Technology, 41.

Rogers, \& Yvonne dan Sara Price. (2009). How Mobile Technologies are Changing the Way Children Learn. Mobile Technology for Children Designing for Interaction and Learning.

Ting, Y.-L. (2011). Using Mobile Technologies to Create Interwoven Learning Interaction: an Intuitive Desaign And Its Evaluation. Computer \& Education: An International Journal, 60, 1-13. 